\title{
GELFOAM INDUCED CAUDA EQUINA SYNDROME: A CASE REPORT WITH REVIEW OF LITERATURE
}

\section{Nazim Mughal* \\ Deepankar Mishra}

Ajay Srivastava

Nikhat Naaz
Assistant Professor, Dept. of Orthopaedic Surgery, Rajshree Medical College, Bareilly, UP (India) * ${ }^{*}$ orresponding Author

Assistant Professor, Dept. of Orthopaedic Surgery, Rajshree Medical College, Bareilly, UP (India)

Assistant Professor, Dept. of Orthopaedic Surgery, Rajshree Medical College, Bareilly, UP (India)

ABSTRACT Gelatin sponge (Gelfoam) is quite often used for haemostasis during spine surgery. However due to its property of osmotic expansion after coming in contact with blood, it has the potential to cause serious complications as a result of compression of nearby vital neurological tissues. We report a case of cauda equina syndrome due to retained Gelfoam during spinal surgery. A 35 year old female patient presented with complaints of pain and numbness in lower limbs for 5 months. MRI was suggestive of disc herniation at L4/L5. Lumbar discectomy was done and gelfoam was used for haemostasis. However, patient developed post-operative neurological complications suggestive of cauda equina syndrome. MRI showed gelfoam induced compression of dural sac. Gelfoam removal was done after which marked improvement in symptoms was observed. Conclusion: Hemostatic agents like Gelfoam which are often used during surgeries have the potential to cause compression of vital structures. Therefore, these should be removed once haemostatic control is accomplished and if it is to be retained, prompt post operative monitoring is essential.

\section{KEYWORDS : Gelfoam, cauda equina syndrome, hemostasis, disc hemiation}

\section{INTRODUCTION :}

Absorbable gelatin sponges have been used for the control of bleeding during spinal surgery since the mid 1940s. (Abbott \& Coleman, 1946; Frantz et al., 1944) They are commonly used world-wide and have been investigated regarding homeostasis, antigenicity, absorbability and scar adhesion prevention.(Gill et al., 1979; Lindstrom, 1956) (Yong-Hing et al., 1980) There have been adverse reactions. Herndon reported two cases of neurological compromise after Gelfoam use.(Herndon et al., 1972) One case involved intracranial use of the sponge, and the other involved thoracic spinal cord compromise after thoracic decompression and grafting. We report a case of gelatin sponge (Gelfoam) induced dural sac compression leading to cauda equine syndrome.

\section{CASE REPORT:}

A 35-year-old female presented in orthopaedic outpatient with pain in legs bilaterally for 5 months along with numbness of bilateral feet. The numbness was present along anterior aspect of right leg and anterior aspect of both feet. She had difficulty in walking due to pain in both legs and her pain free walking duration was less than 5 minutes. She had difficulty in passing urine and her bowel function was normal. There was no history of fever or any other constitutional symptoms. On physical examination, there was mild tenderness over lumbar spine. Her SLRT was bilaterally negative and lower limb power according to MRC grading was bilateral knee flexion 5/5, bilateral knee extension 4/4, bilateral hip abduction $5 / 5$, bilateral ankle planter flexion $5 / 5$, bilateral extensor hallucis longus $4 / 5$ and right-side ankle dorsiflexion being $4 / 5$, left ankle dorsiflexion $5 / 5$. Sensory examination showed decreased sensation to pinch and light touch over bilateral L4 and L5 dermatomes. Deep tendon reflexes and rectal tone were normal. Anal reflex was present and bilateral pedal pulses were palpable and comparable. After radiological evaluation she was found to have lumbar disc herniation at the level of L4-L5 (Fig 1). In view of her condition she was planned for L4/L5 discectomy under general anaesthesia. Intra operative laminectomy, flavectomy and discectomy were performed at L4/L5 Level. Gelfoam of approximate size of $10 \mathrm{~mm} \times 6 \mathrm{~mm}$ was put over dural sac at the surgical site and later wound was closed in layers. Her immediate post-operative period was uneventful, she was mobilized on $1^{\text {st }}$ post- operative day and was comfortable walking independently. On post-operative day 3 , patient reported bilateral leg numbness along with decreased sensation in perianal area. She also complained of inability to pass urine. Her post operative neurological examination revealed bilateral ankle dorsiflexion $3 / 5$, bilateral extensor hallucious longus (3/5). Sensory examination showed decrease sensation over bilateral L5, S1 dermatomes with S2 \& S3 dermatomal hypoesthesia. Her rectal tone was diminished, bilateral pedal pulses were palpable and comparable. MRI showed compression of dural sac under retained gel foam (Fig 2). She was planned for immediate surgical decompression and gel foam removal. Fig 3 shows MRI images of patient after gelfoam removal (Fig 3). On post operative day 1 of the second procedure, she had shown significant improvement in her neurological status with bilateral knee flexion 5/5, bilateral knee extension 5/5, bilateral hip abduction $5 / 5$, bilateral ankle dorsiflexion $4 / 5$, and bilateral extensor hallucis longus $4 / 5$. Her sensory examination showed improvement in her perianal sensation. She was discharged on post-operative day 8 and was followed up subsequently in OPD. After 6 months follow up in OPD, she had mild back pain without any leg pain, no difficulty in passing urine and normal bowel function. Her motor examination showed bilateral ankle dorsiflexion $5 / 5$, bilateral EHL 5/5, normal rectal tone. Her ultrasound pelvis shows no residual urine.

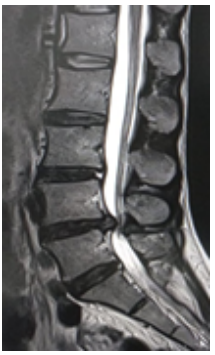

1 (a)

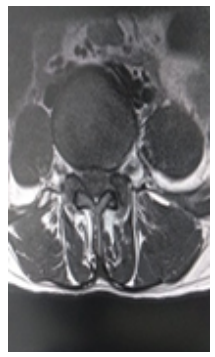

1 (b)
Fig 1 Pre-operative MRI showing L4/L5 disc herniation. 1(a) Sagittal T2 image; 1 (b) Axial T2 image 


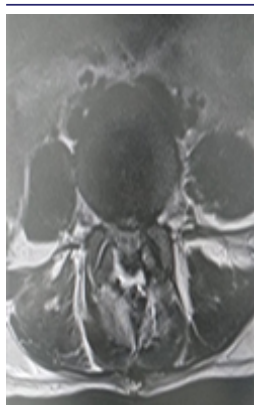

2(a)

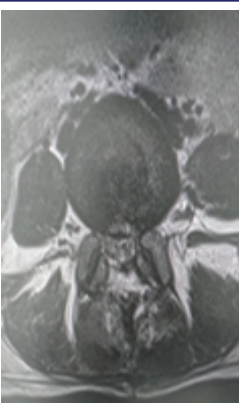

2(b)

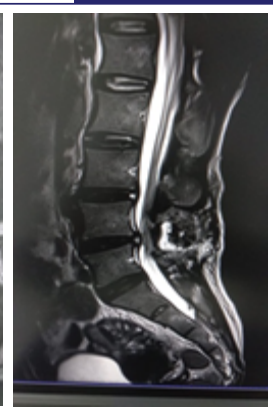

2(c)

Fig 2 MRI after Lumbar dissectomy L4-L5 showing compression of dural sac due to gelfoam. 2(a) \& (b) T2 Axial image; 2(c) T2 Sagittal image

Table 1: Summary of case reports of neurological compromise due to use of intraoperative haemostatic agents.b

\begin{tabular}{|c|c|c|c|c|c|}
\hline References & Procedure & $\begin{array}{c}\text { Hemostatic } \\
\text { agent }\end{array}$ & Clinical findings & MRI & $\begin{array}{l}\text { Outcome after re- } \\
\text { surgery }\end{array}$ \\
\hline $\begin{array}{l}\text { (Alander et al., } \\
\text { 1995) }\end{array}$ & $\begin{array}{l}\text { C5 and } \mathrm{C} 6 \text { corpectomy } \\
\text { with fibular strut allograft. }\end{array}$ & Gelfoam & \begin{tabular}{|l} 
Frankel B \\
quadriparesis.
\end{tabular} & $\begin{array}{l}\text { Mass between allograft } \\
\text { and cord on MRI. }\end{array}$ & $\begin{array}{l}\text { Frankel D } \\
\text { quadriparesis. }\end{array}$ \\
\hline $\begin{array}{l}\text { (Epstein et al., } \\
\text { 2009) }\end{array}$ & $\begin{array}{l}\text { C6-C7 laminectomy and } \\
\text { C2-T2 fusion. }\end{array}$ & Gelfoam & $\begin{array}{l}\text { Progressive } \\
\text { myelopathy } \\
\text { between } 2 \text { and } 3 \\
\text { weeks } \\
\text { postoperatively. }\end{array}$ & $\begin{array}{l}\text { MRI findings concerning } \\
\text { for compression caused } \\
\text { by hematoma/seroma, } \\
\text { infection, or retained } \\
\text { hemostatic agents. }\end{array}$ & $\begin{array}{l}\text { Immediate } \\
\text { improvement } \\
\text { postoperatively. } \\
\text { Required course of } \\
\text { antibiotics for positive } \\
\text { intraoperative culture }\end{array}$ \\
\hline $\begin{array}{l}\text { (D Thavarajah } \\
\text { et al., 2010) }\end{array}$ & $\begin{array}{l}\text { C5-C6 anterior cervical } \\
\text { discectomy and fusion. }\end{array}$ & DuraSeal & $\begin{array}{l}3 / 5 \text { upper and } 2 / 5 \\
\text { lower limb strength } \\
3\end{array}$ & $\begin{array}{l}\text { MRI demonstrating } \\
\text { Cervical cord } \\
\text { compression } \\
\end{array}$ & $\begin{array}{l}\text { Rapid improvement in } \\
\text { upper (4/5) and lower } \\
(3 / 5) \text { limb strength. }\end{array}$ \\
\hline $\begin{array}{l}\text { Herndon et al., } \\
\text { 1972) }\end{array}$ & $\begin{array}{l}\text { Transthoracic vertebral } \\
\text { body exicison for wedge }\end{array}$ & Gelfoam & \begin{tabular}{|l|} 
Brown-Sequard \\
syndrome, urinary \\
incontinence, \\
decreased anal \\
sphincter tone. \\
\end{tabular} & None. & Full recovery in 6 days. \\
\hline $\begin{array}{l}\text { (Menovsky et } \\
\text { al., 2011) }\end{array}$ & L2-L3 laminectomy. & $\begin{array}{l}\text { Surgicel } \\
\text { Fibrillar }\end{array}$ & $\begin{array}{l}\text { Pain on } \\
\text { postoperative day } \\
1 .\end{array}$ & $\begin{array}{l}\text { Dural compression } \\
\text { suspicious for } \\
\text { hematoma on MRI. }\end{array}$ & $\begin{array}{l}\text { Full recovery, } \\
\text { discharged in } 1 \text { week }\end{array}$ \\
\hline $\begin{array}{l}\text { (Friedman, J., et } \\
\text { al., 2001) }\end{array}$ & $\begin{array}{l}\text { L2-L5 posterior } \\
\text { decompression and } \\
\text { instrumented fusion. }\end{array}$ & Gelfoam & $\begin{array}{l}\text { Cauda equina } \\
\text { syndrome } 13 \text { days } \\
\text { postoperativel }\end{array}$ & $\begin{array}{l}\text { None (precluded by } \\
\text { patient factors). }\end{array}$ & $\begin{array}{l}\text { Incomplete recovery by } \\
\text { postoperative day } 2 .\end{array}$ \\
\hline
\end{tabular}

\section{DISCUSSION AND CONCLUSION:}

Absorbable gelatin foam (Gelfoam) was introduced as a haemostatic agent in 1945.(Light \& Prentice, 1945) It is made from animal-skin gelatin after being whipped and baked into sponge form. Although derived from animals, it is largely considered non-antigenic. (Spengler \& Dan M., 1998) Several agents are used to control bleeding which work by providing a matrix framework for a clot to form and thus are designed to control oozing in instances of haemorrhage from multiple tiny vessels. Gelfoam helps form a bulky clot in vascular areas. It is usually wetted with isotonic saline to allow pliability (saline) and with thrombin to enhance clot formation. The surface bonding property of gelfoam is strong and its effect is probably mostly mechanical on low-pressure bleeders and provides a physical matrix to stabilize clots. It can be left in the surgical site and usually gets absorbed within 4 to 6 weeks. (King et al., 2008) There had been few reported adverse effects from Gelfoam use owing to its property of osmotic expansion after coming in contact with blood. Gelfoam when used in an enclosed space containing neural tissue or near the spinal cord may expand and block the drainage areas and may lead to spinal cord compression and neural compromise.(Alander et al., 1995) Table 1 - summarizes existing documented patients with neurologic compromise caused by various retained haemostatic agents used during spinal surgery (Table 1). Postoperative imaging (Fig-2) of symptomatic neurologic compression caused by retained Gelfoam in relation to lumbar spine surgery is often complicated due to the fact that the appearance of the

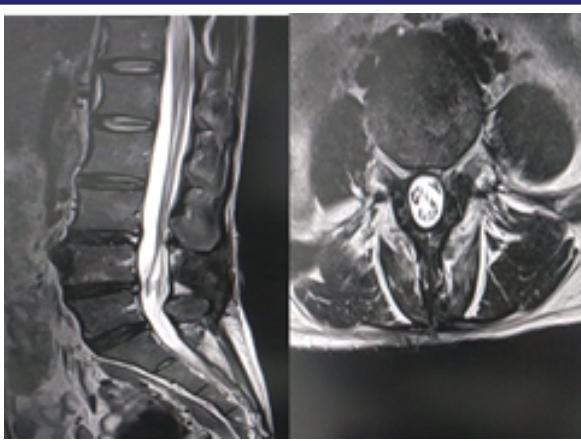

$3(a)$

3 (b)

Fig 3 Post-operative MRI after gelfoam removal 3 (a) Sagittal T 2 image; 3(b) Axial T2 image

substances on MRI can be confused with an epidural hematoma or a recurrent herniation. (Partheni et al., 2006) (Schwartz \& R.B., 2002) While the utility of haemostatic agents in spinal surgery cannot be disputed, it is important to use caution when employing various commercially available haemostatic agents, especially when they are retained in the wound. Many manufacturers recommend removal of these products when used in areas sensitive to compression. Increased awareness of their potential to cause harm may help surgeons avoid further postoperative complications. Large pieces of Gelfoam should not be packed between an interbody bone graft and dural sac. The use of Gelfoam does have the potential to compress vital structures within an enclosed space. Small pieces of Gelfoam applied to specific bleeding sites may be used to ensure meticulous haemostasis. But in our case placing a small piece of gelfoam caused compression and lead to cauda equine syndrome. Hence Gelfoam should be removed once haemostatic control is accomplished and if it to be retained prompt post operatively monitoring is needed.

\section{REFERENCES:}

1. Abbott, W. D., \& Coleman, F. C. (1946). THE USE OF GELATIN SPONGE IN NEUROSURGERY. Journal of the American Medical Association, 132(6), 329-330. https://doi.org/10.1001/jama.1946.02870410017006

2. Alander, D.H., Stauffer, \& E.S. (1995). Gelfoam-induced acute quadriparesis after cervical decompression and fusion. Spine, 20(8), 970-971. https://doi.org/10.1097/00007632-199504150-00016

3. D Thavarajah, P De Lacy, R Hussain, \& RM Redfern. (2010). Postoperative cervical cord compression induced by hydrogel (DuraSeal): A possible complication. Spine, 35(1). https://doi.org/10.1097/BRS.0b013e3181b9fc45 
4. Epstein, N.E., Silvergleid, R.S., Hollingsworth, \& R. (2009). Increased postoperative cervical myelopathy and cord compression resulting from the use of Gelfoam. The Spine Journal : Official Journal of the North American Spine Society, 9(2), el9-e21.https://doi.org/10.1016/j.spinee.2008.03.009

5. Frantz, V. K., Clarke, H. T., \& Lattes, R. (1944). Hemostasis With Absorbable Gauze (Oxidized Cellulose). Annals of Surgery, 120(2), 181. https://doi.org/10.1097/00000658-194408000-00005

6. Friedman, J. Whitecloud III \& TS. (2001). Lumbar cauda equina syndrome associated with the use of gelfoam: Case report. Spine, 26(20), E485-E487. https://doi.org/10.1097/00007632-200110150-00029

7. Gill, G.G., Sakovich, L., \& E.L.L.E.N. (1979). Pedicle fat grafts for the prevention of scar formation after laminectomy. An experimental study in dogs. Spine, 4(2), 176-186. https://doi.org/10.1097/00007632-19790300000016

8. Herndon, J. H., Grillo, H. C., Riseborough, E. J., \& Rich, J. C. (1972). Compression of the Brain and Spinal Cord Following Use of Gelfoam. Archives of Surgery, 104(1), 107-107. https:// doi. org/10. 1001/archsurg.1972.04180010101027

9. King, T.J., Sullivan, \& E.M. (2008). In Physician Asisstant. WB Sanders.

10. Light, R. U., \& Prentice, H. R. (1945). Surgical Investigation of a New Absorbable Sponge Derived from Gelatin for Use in Hemostasis. Journal of Neurosurgery, 2(5), 435-455. https://doi.org/10.3171/jns.1945.2.5.0435

11. Lindstrom, P. A. (1956). Complications from the Use of Absorbable Hemostatic Sponges. A.M.A. Archives of Surgery, 73(1), 133-141. https://doi. org/10. 1001/archsurg.1956.01280010135018

12. Menovsky, T., Plazier, M., Rasschaert, R., Maas, A. I., Parizel, P., \& Verbeke, S. (2011). Massive Swelling of Surgicel $\AA^{\circledR}$ FibrillarTM Hemostat after Spinal Surgery. Case Report and a Review of the Literature. Min - Minimally Invasive Neurosurgery, 54(05/06), 257-259. https://doi.org/10.1055/s-0031-1284394

13. Partheni, M., Kalogheropoulou, C., Karageogos, N., Panagiotopoulos, V., Voulgaris, Tzortzidis, \& F. (2006). Radiculopathy after lumbar discectomy due to intraspinal retained Surgicel: Clinical and magnetic resonance imaging evaluation. The Spine Journal : Official Journal of the North American Spine Society, 6(4), 455-458. https://doi.org/10.1016/j.spinee.2005.12.006

14. Schwartz \& R.B. (2002). Hyperperfusion encephalopathies: Hypertensive encephalopathy and related conditions. The Neurologist, 8(1), 22-34. https://doi.org/10.1097/00127893-200201000-00003

15. Spengler, \& Dan M. (1998). Essentials of Spinal Microsurgery-ProQuest. Journal of Bone and Joint Surgery, 81(7), 1050.

16. Yong-Hing, K., Reilly, J., Korompay, V. de, \& Kirkaldy-Willis, W. H. (1980) Prevention of Nerve Root Adhesions After Laminectomy. Spine, 5(1), 59-64. 